\title{
Xanthomatous meningioma; a rare histological variant
}

\author{
Jasim M. A Al-Diab', Hasan H. Almohammed ${ }^{2}$,Sura A. Al-Namil ${ }^{3}$
}

\section{ABSTRACT}

Introduction: Meningiomas are tumors of the central nervous system originating from the meningothelial tissues, the arachnoid cap cells of the cranium and spinal cord. According to the WHO classification system, grade 1 meningiomas are of nine subtypes. Xanthomatous meningioma is a rare histological variant of meningioma belong to the subtype "Metaplastic meningioma". The Meningioma with a predominantly xanthomatous cellular changes with lipid-laden vacuolated cytoplasm is classified as "xanthomatous meningioma"

Case report: A 61 year old patient presented with headache, disorientation and hemiparesis. Magnetic resonance imaging (MRI) shows large right parietal enhancing dural based convexity meningioma. The tumor resected enblock and the histological examination revealed features of classical meningioma with predominant areas of xanthomatous changes. Immunostaining for epithelial membrane antigen and vimentin wase positive in both xanthomatous foamy cells and meningothelial areas. GFAP was negative. CD 68 was positive in few scattered cells in the xanthomatous areas. Ki-67 index was $1 \%$ in the highly cellular area. The final histopathological diagnosis was xanthomatous meningioma, WHO grade I.

Conclusion: Xanthomatous meningioma is a rare variant of meningioma belongs to the subtype metaplastic meningioma. We present the case because it is an extremely rare worldwide.

Key words: Meningioma, xanthomatous, rare histological variant

$$
\text { الاورام السحائية الزانثومية، نوع نسيجي نادر }
$$

المقدمة: الاورام السحائية هي اورام الجهاز العصبي المركزي الذي ينشأ من الانسجة السحائية العنكبوتية في الجمجمة والحبل الشوكي. ووفقا لنظام تصنيف منظمة الصحة العالمية ، فأن الاورام السحائية ذات الدرجة الاولى تتكون من تسعة انواع فرعية. الورم السحائي الزانثومي هو نوع نادر من الورم

$$
\text { السحائي ينتمي الى النوع الفرعي الورم السحائي المتحول }
$$

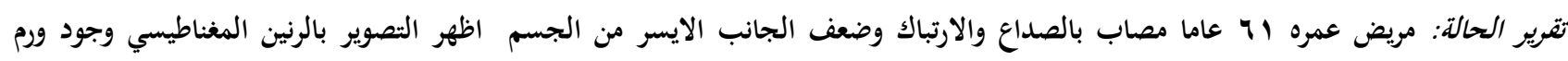
سحائي كبير على الجافية. ازيل الورم كاملات وارسل الى الفحص النسيجي الذي اظهر ملامح ورم السحائي الكلاسيكي مع المناطق السائدة من

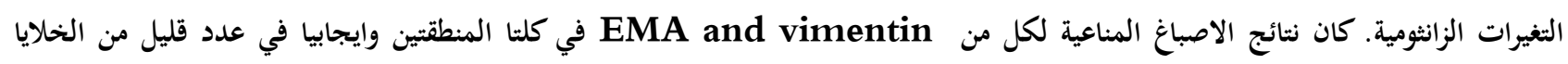

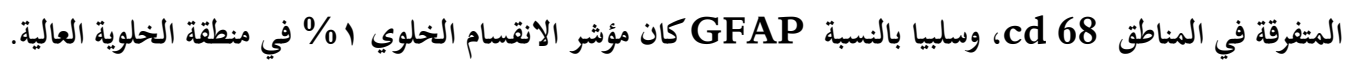
كان التشخيص المرضي النهائي هو ورم سحائي زانثومي. الخلاصة: الورم السحائي الزانثومي هو نوع نادر من الاورام السحائية ينتمي الى الاورام السحائية شبة النمطية. ننشر هذه الحالة لأنها نادرة على المستوى العالم. الكلمات المفتاحية: الاورام السحائية، الزانثومية، نوع نسيجي نادر المر

\section{INTRODUCTION}

anthomatous meningiomais a rare components. They include the cartilaginous
histological variant of meningiomas meningioma, lipomatous meningioma,
belong to the subtype melanotic meningioma, myxoid meningioma,

\footnotetext{
${ }^{1}$ Professor of Pathology, Basrah Medical College

${ }^{2}$ Consultant Neurosurgeon, Al-Sader Teaching Hospital, Basrah

${ }^{3}$ Specialist in Pathology, Al-Sader Teaching Hospital, Basrah
} 
xanthomatous cellularchanges with lipid-laden vacuolated cytoplasm is classified as "xanthomatous meningioma". ${ }^{[1,2]}$ Xanthomatousmeningiuoma, as a variant of metaplastic meningioma is included in the WHO grade I tumors. According to the World Health Organization (WHO) classification, grade I meningiomas are of nine types; meningothelial, fibrous, transitional, psammomatous, angiomatous, microcystic, secretory, lymphoplasmacyte rich, and metaplastic types(2). The classification of meningiomas has not been revised in the WHO 2016 classification. $^{[1]}$ Xanthomatous meningioma needs to be distinguished from the grade 2 clear cell meningiomawhich is characterized by poorer prognosis with a higher recurrence rate. ${ }^{[3]}$

\section{Case report}

Our patient was 61 year old male presented with headache, convulsion and left hemiparesis. Clinical examination reveals cloudy conscious level, disorientation and grade 4+ left hemiparesis. Brain magnetic resonance imaging revealed a large ( $5 \mathrm{~cm}$. in maximum dimention) extra axial well defined right dura based parietal strongly enhancing mass (Fig-1).

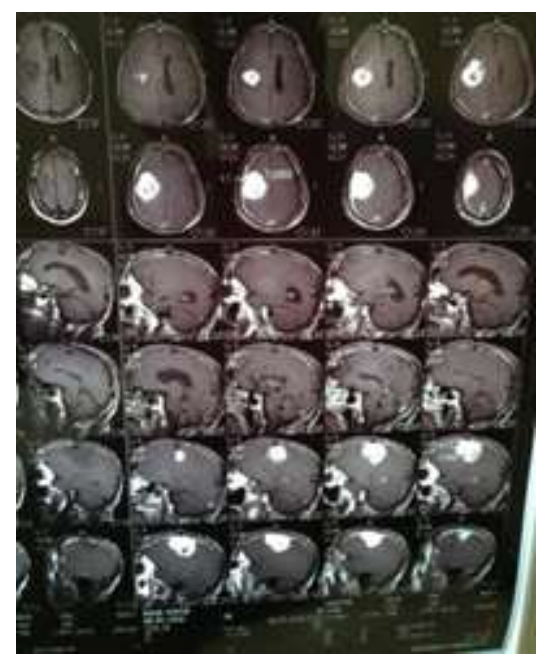

Fig 1. Brain magnetic resonance imaging revealed a large extra axial well defined right dura based parietal strongly enhancing mass
The mass was resected enblock and sent for the histopathological laboratory. The macroscopic examination revealed lobulated mass; measures $5 \times 4 \times 4 \mathrm{~cm}$. with smooth outer surface and a piece of dura attached to it. The cut surface was orange yellow in color, firm with small cystic areas (Fig-2).

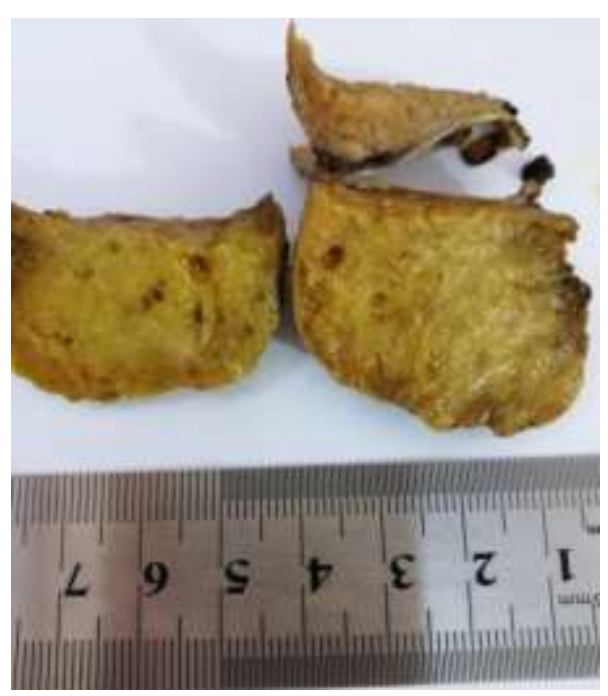

Fig 2. Cut surface of the tumor is orange yellow in color with small cystic areas

The microscopic examination revealed diffuse growth pattern of meningothelial cells with many whorls and prevalent areas of polygonal cells with clear vacuolated, foamy cytoplasm (xanthomatous changes). The nuclei are uniform nuclei, atypia, no necrosis and no mitotic activity (Fig-3). 

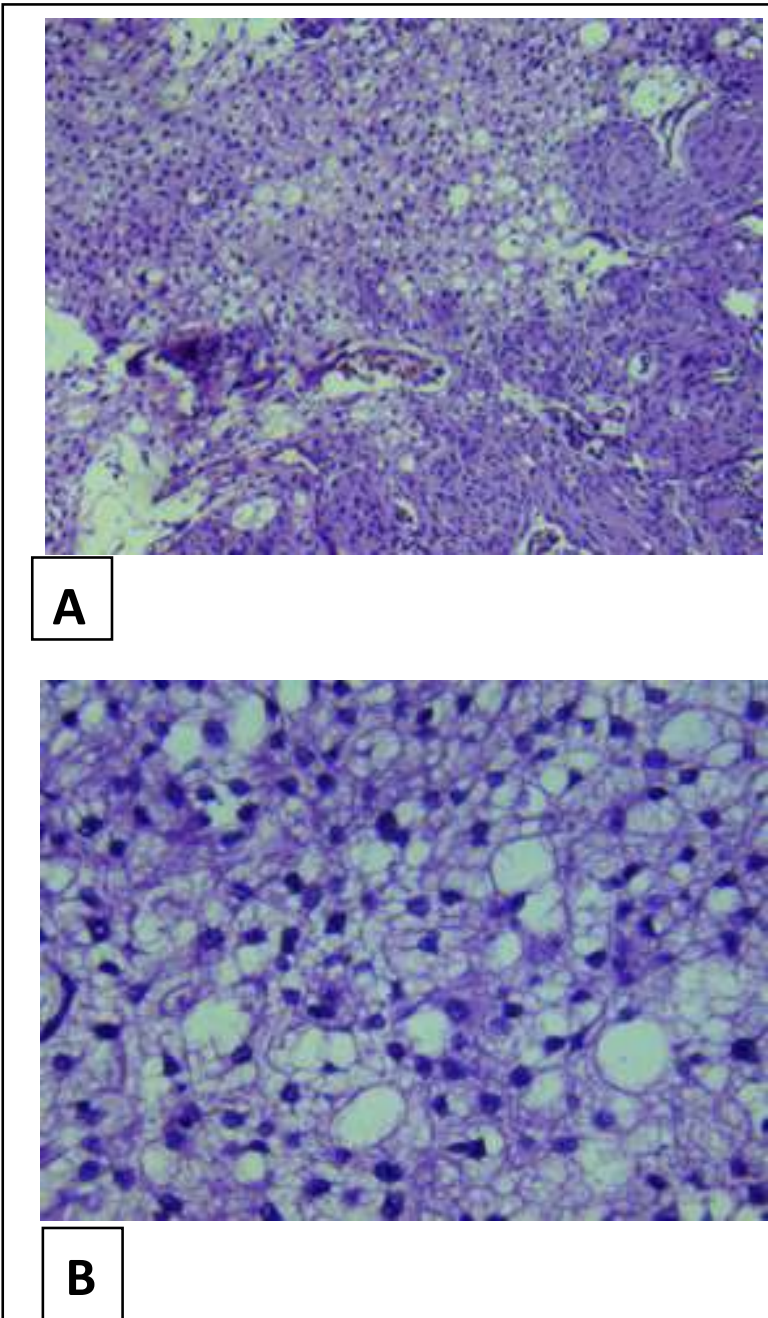

Fig 3. Heamatoxilin Eosin stained section showed (A) biphasic pattern of meningothelial cells with whorls and prevalent areas of polygonal cells with clear vacuolated, foamy cytoplasm (xanthomatous changes) (B)
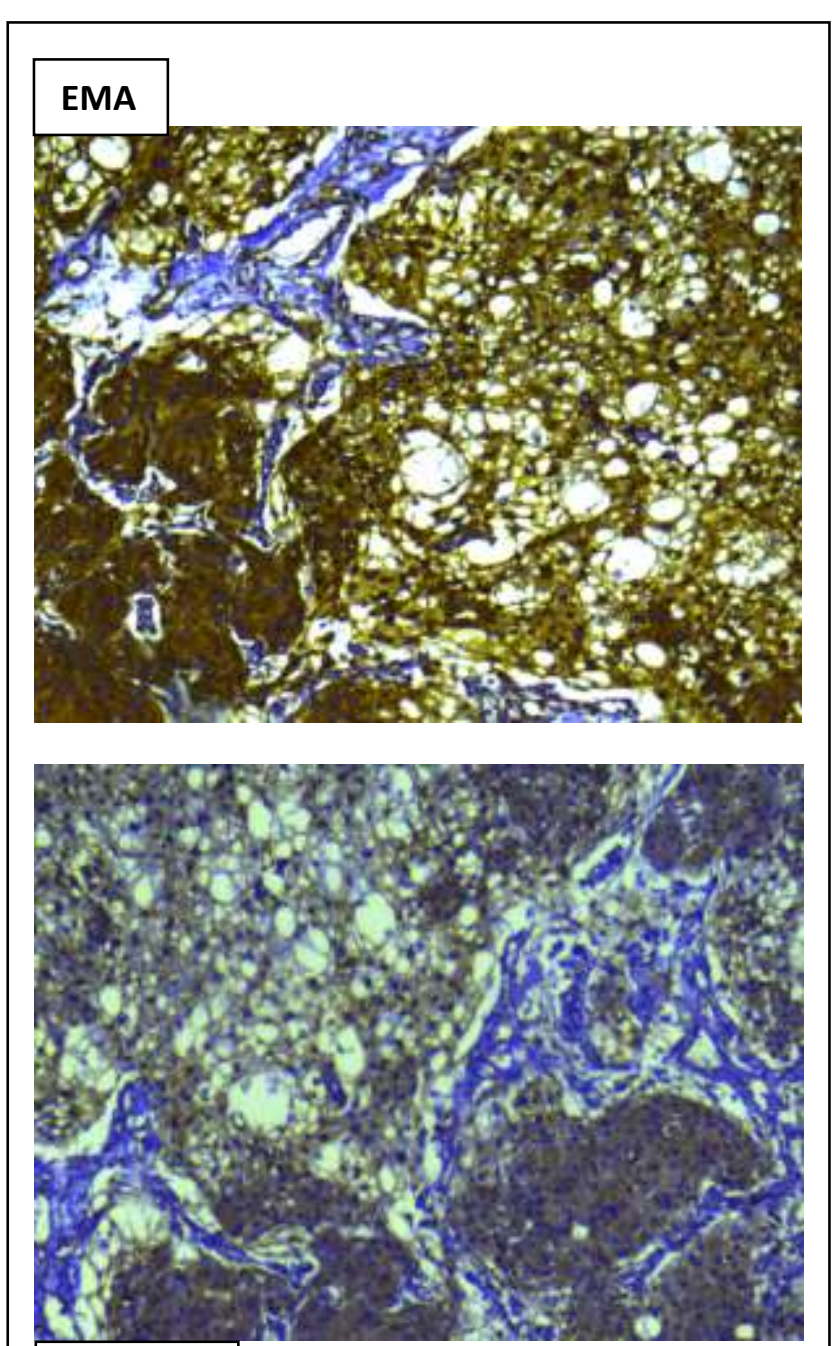

\section{Vimentin}

Fig 4. Positive epithelial membrane antigen (EMA) and vimentin staining in both meningothelial and xanthomatous areas

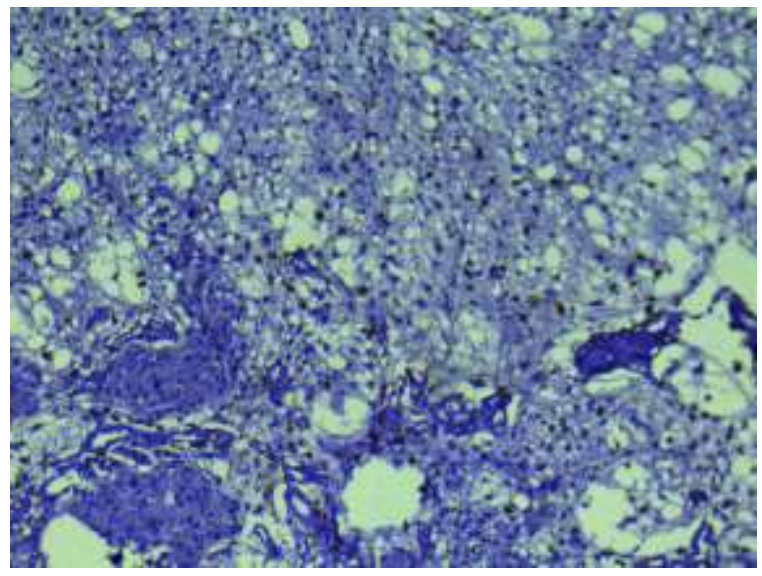

Fig 5. few scattered CD68 positive cells in the xanthomatous area. 
Meningiomas, so named by Harvey Cushing in 1922, are common primary intracranial tumor. They are thought to originate from the arachnoid cap cells (cells forming the outer lining of the arachnoid membrane) of the meninges. Whether the arachnoid cap cells are derived from the neural crest or the mesoderm is itself still controversial ${ }^{[4]}$ Grossly most meningiomas are well defined, round or oval, frequently lobulated tumors attached to the dura. The benign meningioma may compress the adjacent brain but not invade it. Most meningiomas are hard to firm in consistency, and on cut surface the typical meningioma is a greyish pink homogenous tumor. Occasionally, yellow flaks representing collection of fat containing cells (xanthoma) are seen. ${ }^{[7]}$ Microscopically meningioma are composed of two parts; the first is the basic cellular constituents which are the meningocytic cells arranged, at least in some places, in specific pattern known as whorl. The second component is made up of different forms of tissues which may be absent, minimal or prominent in the tumor. ${ }^{[10]}$ The term xanthomatous meningioma should be restricted for a meningioma with a predominantly xanthomatous cellular changes with lipid-laden vacuolated cytoplasm ${ }^{[1]}$ Xanthomatous meningioma is a quite rare neoplasm, first described by Kepes in 1994. ${ }^{[4]}$ Few cases have been reported worldwide. ${ }^{[2-6,8]}$ The most important histological criteria for the diagnosis of xanthomatous meningioma is the presence of xanthomatous tumor cells with clear vacuolated foamy cytoplasm (due to their lipid content) and uniform oval centrally located nuclei. ${ }^{[6,8]}$ The xanthomatous cells are morphologically similar to macrophages, but positive staining for epithelial membrane antigen (EMA) and vimentinsupports the meningothelial origin of these cells. ${ }^{[2,6]}$ In our case the xanthomatous cells are positive for both EMA and vimentin with few scattered foamy cells that are EMA negative but stained positive with the histiocytic marker CD 68. These CD 68 positive foamy cells may be macrophages that had immigrated to the tumor due to degeneration. ${ }^{[6]}$ However, CD68 positivity does not always indicate the histiocytic nature of the cells, it may also reflect the presence of abundant lysosomes in the cytoplasm of the xanthomatous cell. Yet, EMA positivity still the most important stain that support the meningothelialorigin of the tumor. ${ }^{[2,6]}$ Ishida, et $\mathrm{al}^{[2]}$ observed adipophilin positivity in both xanthomatous and conventional areas of meningioma. Adipophilin demonstrates lipid droplets in cytoplasm of the tumor cells. However, we didn't use the adipophilin in our case, the foamy appearance was so clear to suggest xanthomatous nature of the tumor cells which are proved to be of meningothelial origin by EMA and vimentin. Xanthomatous meningioma, is classified as grade I meningioma. It needs to be distinguished from the grade II clear cell meningioma which is characterized by poorer prognosis with a higher recurrence rate. ${ }^{[3]}$ Another Differential diagnosis of xanthomatous meningioma is the lipomatous meningioma which is characterized by the presence of adipose tissue and it is a very rare subtype of meningioma. The adipocyte-like cells seen in lipomatousmeningiomas were reported to be $S-100$ positive. ${ }^{[9]}$ In our current case, we didn't demonstrate adipocyte-like cells in the tumor

\section{CONCLUSION}

Xanthomatous meningioma is a rare variant of meningioma belongs to the subtype "Metaplastic meningioma". Their diagnosis depends on the presence of an appreciated xanthomatous changes in the cytoplasm of the tumor cells together with the presence of conventional meningothelial growth pattern. Awareness should be raised toward this rare variant of meningioma to avoid misdiagnosis. 


\section{REFERENCES}

1. Safak ERSOZ, ZeynepSagnak YILMAZ, Ilker EYUBOGLU and Ugur YAZAR.Xanthomatous Meningioma: A Case Report. Turk Neurosurg, February. 2017. DOI: 10.5137/10195149.JTN.19561-16.1

2. Ishida M, Fukami T, Nitta N, Iwai M, Yoshida K, Kagotani A, Nozaki $K$, Okabe $H$ : anthomatous meningioma: $A$ case report with review of the literature. Int J ClinExpPathol.2013; 6(10): 2242-2246.

3. Chougule M, Pawar V, Chivate SD, Sunil VJ: Xanthomatous meningioma-A rare case report. IJHSR. 2015; 5: 445-448.

4. Kepes JJ: Lipidizedmeningothelial tumor cells in"xanthomatous" meningioma express macrophage antigen. J. NeuropatholExp Neurol.1994; 53: 384-388.

5. Ijiri R, Tanaka Y, Hara M, Sekido K: Radiationassociated xanthomatous meningioma in a child. Childs Nerv Syst.2000; 16:304-308.
6. Ikota $H$, Nakazato $Y$ : A case of metaplastic meningioma with extensive xanthomatous change. Neuropathology. 2008; 28:422-426.

7. Russel DS, Rubinstien LJ. Pathology of tumors of the nervous system. $5^{\text {th }}$ edition, Williams \& Wilkins. Baltimore. 1989; 693-695.

8. Colen CB, Rayes M, McClendon J Jr, Rabah R, Ham SD: Pediatric spinal clear cell meningioma: A case report. J Neurosurg Pediatr. 2009; 3: 57-60.

9. Gasparinho MG, Ferreira $M$, Lavrador JP, Livraghi S: Revisiting lipomatous meningioma: A case report and review of an unusual entity. Int J SurgPathol. 2015; 23(5): 399-403.

10. LapresleJ, Netsky M, Zimmerman HM. The pathology of meningiomas. American Journal of Pathology. 1952 Oct; 28(5): 757-791. 